\begin{tabular}{|c|c|}
\hline AUb 281996,20 ENGINEERING DATA TRANSMITTAL & 1. EDT $\quad 615776$ \\
\hline
\end{tabular}

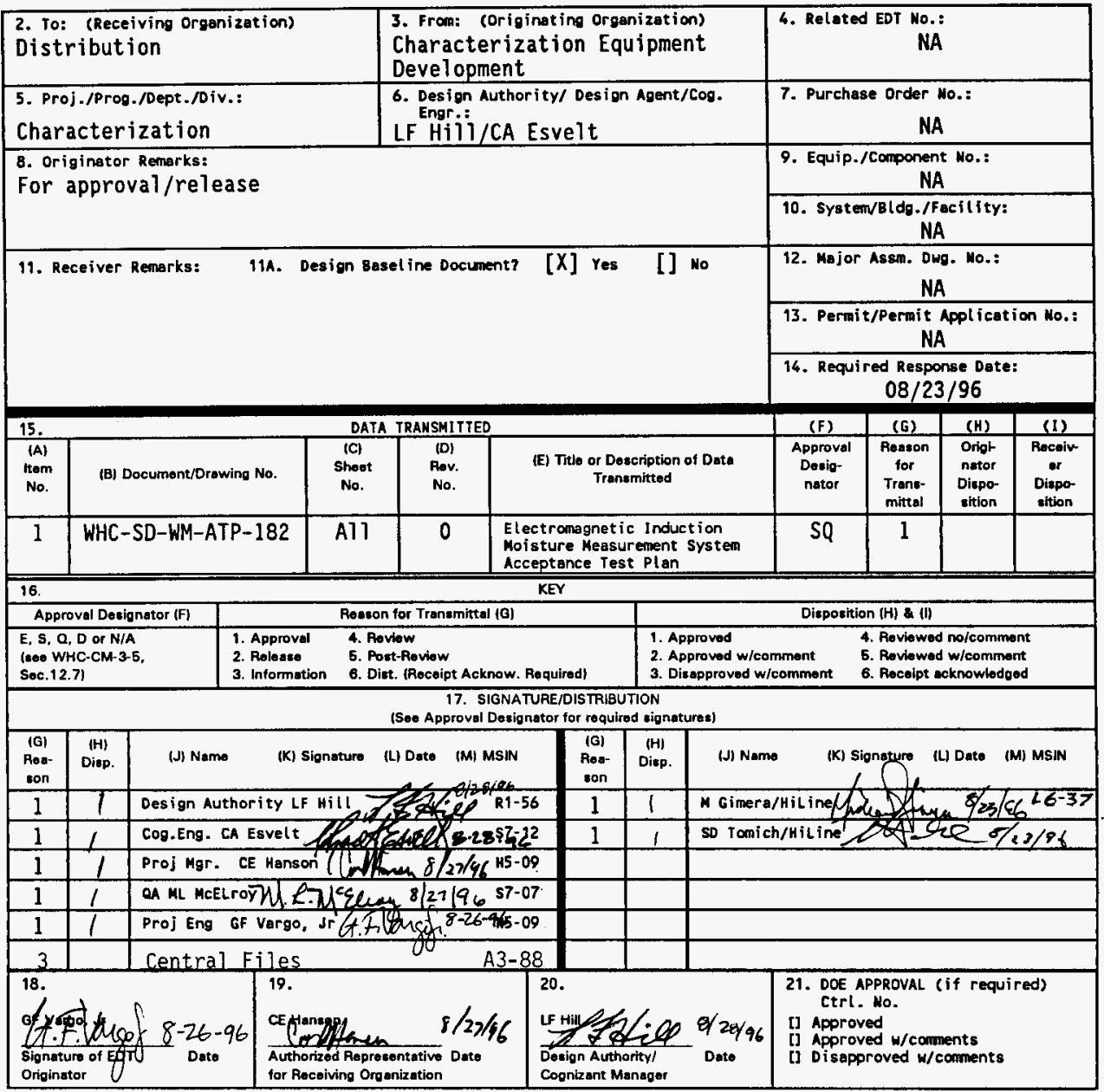

BO-7400-172-2 (05/96) GEF097 


\title{
ELECTROMAGNETIC INDUCTION MOISTURE MEASUREMENT SYSTEM ACCEPTANCE TEST PLAN
}

\author{
HiLine Engineering for \\ Westinghouse Hanford Company, Richland, WA 99352 \\ U.S. Department of Energy Contract DE-ACO6-87RL10930
}

$\begin{array}{lll}\text { EDT/ECN: } & 615776 & \text { UC: } 2070 \\ \text { Org Code: } & 75250 & \text { Charge Code: } \\ \text { B\&R Code: } & \text { EW3120074 } & \text { Total Pages: } 37\end{array}$

Key Words: Electromagnetic Induction (EMI), Surface Moisture Measurement System (SMMS), probe, acceptance test plan, tanks.

Abstract: The purpose of this acceptance test plan (ATP) is to verify that the mechanical, electrical, and software features of the ElectroMagnetic Induction (EMI) probe are operating as designed, and that the unit is ready for field service. The accepted EMI and Surface Moisture Measurement Systems (SMMS) will be used primarily in support of Tank Waste Remediation System (TWRS) Safety Programs for moisture measurement of organic and ferrocyanide watch list tanks.

TRADEMARK DISCLAIMER. Reference herein to any specific commercial product, process, or service by trade name, trademark, menufacturer, or otherwise, does not necessarily constitute or imply its endorsement, recommendation, or favoring by the United States Goverment or any agency thereof or its contractors or subcontractors.

Printed in the United States of America. To obtain copies of this document, contact: HHC/BCS Document Control Services, P.O. Box 1970, Mailstop H6-08, Richland WA 99352, Phone (509) 372-2420; Fax (509) 376-4989.
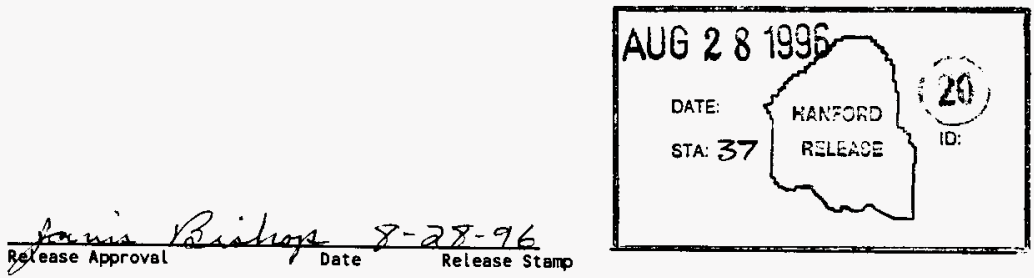

\section{Approved for Public Release}


WHC-SD-WM-ATP-182, REV. 0

\title{
ELECTROMAGNETIC INDUCTION MOISTURE MEASUREMENT SYSTEM ACCEPTANCE TEST PLAN
}

\author{
ISSUED BY \\ G.F. VARGO, JR. \\ S.D. TOMICH \\ M. GIMERA
}

August 1996 
WHC-SD-WM-ATP-182, REV. 0

TABLE OF CONTENTS

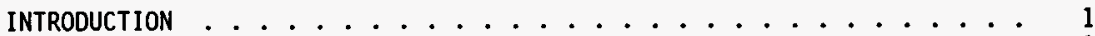

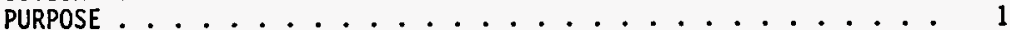

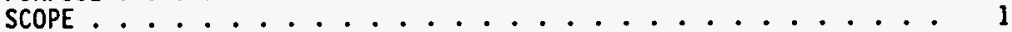

GENERAL EQUIPMENT DESCRIPTION ............... 1

EMI MOISTURE MEASUREMENT SYSTEM .............. 2

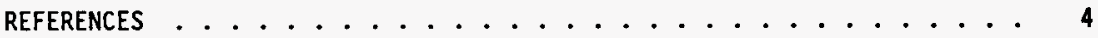

ELECTRICAL AND MECHANICAL ACCEPTANCE TEST PROCEDURE FOR ELECTROMAGNETIC

INDUCTION MOISTURE MEASUREMENT SYSTEM ........... 6

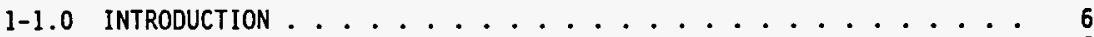

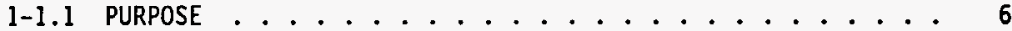

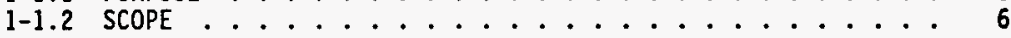

$1-2.0$ TEST CONTROLS . . . . . . . . . . . . . . . 7

1-2.1 RESPONSIBILITIES ASSOCIATED WITH TESTING AT $306 \mathrm{E} \ldots \ldots 7$

$1-2.2$ TEST DATA . . . . . . . . . . . . 8

$1-2.3$ TEST CONFIGURATION . . . . . . . . . . . . . 8

$1-2.4$ PROCEDURE CONTROL ...................... 9

$1-2.5$ RETEST PROCEDURE CONTROL . . . . . . . . . . . g g

$1-2.6$ EXCEPTIONS TO ACCEPTANCE TEST SECTION ......... 9

$1-3.0$ TEST CONDITIONS AND EQUIPMENT REQUIRED . .............. .9

1-3.1 TEST FACILITY . . . . . . . . . . . . 9

$1-3.2$ EQUIPMENT REQUIRED FOR TESTING AT 306E ......... 10

$1-3.3$ FIELD TESTING OPTION .................... 10

1-4.0 SAFETY PRECAUTIONS AND CONTROLS .............. 10

$1-4.1$ PERSONNEL PRECAUTIONS ................... 10

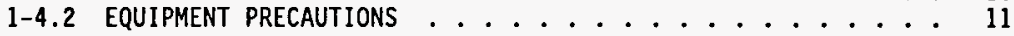

$1-5.0306$ TEST PROCEDURE $\ldots \ldots \ldots \ldots \ldots$

$1-5.1$ PREREQUISITES $\ldots \ldots \ldots 11$

$1-5.2$ ELECTRICAL CONTINUITY CHECKS . . . ........ 11

$1-5.3$ ELECTRICAL SYSTEMS OPERATIONAL CHECKOUT $\ldots \ldots$

$1-5.4$ DEPLOYMENT DEVICE PREOPERATIONAL TEST . . . . . . 14

$1-5.5$ TEST POWER SUPPLY FOR EMI .............. 14

$1-5.6$ FUNCTIONAL TEST $\ldots \ldots \ldots \ldots$ 
WHC-SD-WM-ATP-182, REV. 0

TABLE OF CONTENTS, cont

SOFTWARE ACCEPTANCE TEST PROCEDURE FOR ELECTROMAGNETIC INDUCTION

MOISTURE MEASUREMENT SYSTEM . . . . . . . . . . . . 16

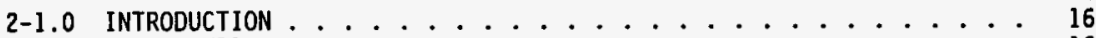

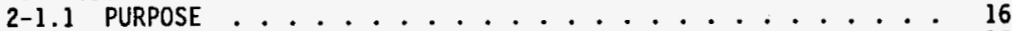

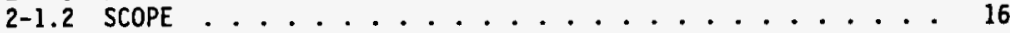

$2-2.0$ SOFTWARE TEST PLAN ..................... 16

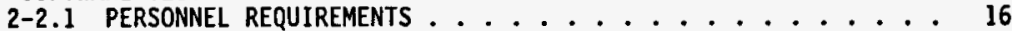

$2-2.2$ FEATURES TO BE TESTED ............... 17

2-3.0 ACCEPTANCE TEST PROCEDURE ................. 18

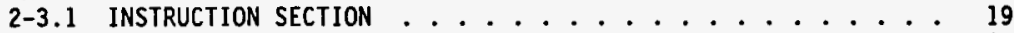

$2-3.2$ TEST EXECUTION SECTION ................... 20

FIGURE $1-1$ EMI MOISTURE MEASUREMENT SYSTEM . . . . . . . . . 22

FIGURE $2-1 \quad$ OPERATOR INTERFACE SCREEN . . ........... 23

APPENDIX A

EMI MOISTURE MEASUREMENT SYSTEM FUNCTIONAL TESTING

OBSERVATION/RESULTS SHEET .................. A A-1

APPENDIX B

EXCEPTIONS TO EMI ACCEPTANCE TEST ................ . . . . .

APPENDIX $C$

PRE-JOB SAFETY MEETING FORM AND ATTENDANCE ROSTER .......... c-1

APPENDIX D

EMI/SMMS CONVERSION PROCEDURE ................ D-I 
WHC-SD-WM-ATP-182, REV. 0

\section{LIST OF TERMS}

$\begin{array}{ll}\text { ALARA } & \text { As Low As Reasonably Achievable } \\ \text { ATP } & \text { Acceptance Test Procedure } \\ \text { CO } & \text { Carbon monoxide } \\ \text { DAV } & \text { Data Acquisition Van } \\ \text { DOT } & \text { U.S. Department of Transportation } \\ \text { ECN } & \text { Engineering Change Notice } \\ \text { EMI } & \text { ElectroMagnetic Induction } \\ \text { EP } & \text { Standard Engineering Practice (WHC-CM-6-1) } \\ \text { JCS } & \text { Job Control System } \\ \text { MCA } & \text { Multi-Channel Analyzer } \\ \text { NEC } & \text { National Electrical Code } \\ \text { OMM } & \text { Operations and Maintenance Manual } \\ \text { SMMS } & \text { Surface Moisture Measurement System } \\ \text { SRS } & \text { Software Requirements Specification } \\ \text { TWRS } & \text { Tank Waste Remediation System } \\ \text { VCR } & \text { Video Cassette Recorder } \\ \text { WHC } & \text { Westinghouse Hanford Company }\end{array}$


WHC-SD-WM-ATP-182, REV. 0

\title{
ELECTROMAGNETIC INDUCTION MOISTURE MEASUREMENT SYSTEM ACCEPTANCE TEST PLAN
}

\author{
INTRODUCTION
}

PURPOSE

The purpose of this acceptance test plan (ATP) is to verify that the mechanical, electrical, and software features of the ElectroMagnetic Induction (EMI) probe are operating as designed, and that the unit is ready for field service. The accepted EMI and Surface Moisture Measurement Systems (SMMS) will be used primarily in support of Tank Waste Remediation System (TWRS) Safety Programs for moisture measurement of organic and ferrocyanide watch list tanks.

SCOPE

This ATP addresses testing of the EMI probe. The EMI tests do not require that the deployment system and enclosure be vertical. Testing will be performed at the $306 \mathrm{E}$ Facility in the 300 Area. The scope of tests to be performed at the facility is described in the following sections, 1 and 2 .

Summary of the Testing Objectives at the 306E Facility

- Verify basic equipment functions and mechanical interfaces.

- Perform pre-operational check of the electrical system.

- Perform overall "loop check" on the system by measuring conductivity of conductivity standards to verify that the EMI probe and supporting electronics are functioning satisfactorily.

GENERAL EQUIPMENT DESCRIPTION

The EMI probe is used as a substitute/alternate detection method for use in the SMMS system for moisture measurements of tank waste.

A more complete description of the SMMS, including detailed operating instructions, is provided in WHC-SD-WM-0MM-024, Surf ace Moisture Measurement System Operation and Maintenance Manual (Ritter et al. 1995).

The EMI probe head is designed to measure the moisture in the near surface layers of tank waste using the eddy current technology. The depth of interrogation depends on the moisture level encountered and the probe must be placed on the surface of the waste to make these measurements.

The EMI Probe screws directly onto the neutron probe interface cable head and uses all existing SMMS wiring from probe head to intrinsic barriers. The EMI Probe has two internal pancake coils. These coils are routed through coaxial cables to a connector, which mates with the cable head connector used for the neutron probe. The coils and connectors are mechanically housed 
WHC-SD-WM-ATP-182, REV. 0

within a probe housing, comprised of stainless steel and semi-conductive polyethylene.

The coaxial cables are routed from the cable head connector, through the SMMS winch box, through a set of mercury wetted slip rings, and terminated on a set of intrinsic barriers specially selected to protect the EMI probe. These barriers were selected to function with EMI signals and to provide an intrinsically safe EMI circuit within the waste tank.

\section{EMI MOISTURE MEASUREMENT SYSTEM}

The EMI system is shown in Figure 1-1 and consists of the following components:

- A probe that consists of two internal pancake coils.

- The EMI/SMMS deployment device that consists of a support mast, an arm, and winch systems to lower and raise the arm and probe.

- Zetec MIZ-40A eddy current instrument.

The full deployment system also includes the addition of:

- A data acquisition van (DAV) that is equipped with the following:

- Control console with flat panel computer system

- Video monitor and video cassette recorder (VCR)

- Electrical power distribution system

- Data processing electronics and software

- A decontamination system that consists of a high pressure spray ring that mounts on the riser, a gas-powered pressure washer, a gas-powered feed pump, a water tank, totalizers, and various hoses and fittings.

The EMI sensor package is an eddy current probe that infers the moisture content of the top layers of the waste surface by measuring the conductivity properties. The probe measures moisture in the range of 0 to $80 \mathrm{~ms} / \mathrm{cm}$. The EMI system was designed to be operated in a National Fire Protection Association (NFPA) hazardous area classified as Class I, Division 1, Group B (see WHC-SD-WM-TI-242).

The deployment device consists of a vertical support mast with a rotating arm, which can be vertically rotated through a controlled angle to position the probe at a radius between 0 and $2 \mathrm{~m}(6 \mathrm{ft})$ from the riser centerline. A deployment cable, guided over the arm, mechanically lowers the probe to the waste surface.

The deployment device interfaces with a DAV that contains the eddy current instrument and records pertinent data. The DAV is a standalone system and connections to existing tank farms utilities are not required. 
Interconnecting cables will be placed above ground and routed between the van and the deployment device. The EMI/SMMS and supporting equipment are portable and only temporarily installed in a waste tank. The deployment device is packaged in a weather-tight container for storage and transportation.

During measurement sequences, the arm will be raised to a specified angle and the deployment device will be rotated to a specified orientation. The probe then will be mechanically lowered until it makes contact with the waste surface. The probe is not intended to penetrate the waste. A separate in-tank camera installed in an adjacent riser will provide visual feedback for all in-tank operations including probe deployment and placement. This in-tank camera is mandatory for successful EMI/SMMS operation. A video monitor will be located next to the riser to help the operator position the probe. 


\section{REFERENCES}

WHC-SD-WM-DA-202, Rev. 0, NEC Hazardous Classification and Compliance Regarding the Surface Moisture Monitor Measurement System, Westinghouse Hanford Company, Richland, Washington.

WHC-SD-WM-ATP-153, Rev. 0, Surface Moisture Measurement System Acceptance Test Procedure, Westinghouse Hanford Company, Richland, Washington.

WHC-SD-WM-DA-242, NFPA Hazardous Classifications and Compliance Regarding the ElectroMagnetic Induction Probe, Westinghouse Hanford Company, Richland, Washington.

WHC-SD-WM-CSDD-017, Software Design Description for SMMS, Westinghouse Hanford Company, Richland, Washington.

WHC-SD-WM-ATP-158, Rev. 0, Sof tware Acceptance Test Procedure for the Surface Moisture Monitor, Westinghouse Hanford Company, Richland, Washington.

WHC-SD-WM-ATP-159, Rev.0, Software Acceptance Test Procedure for the LOW Moisture Monitor, Westinghouse Hanford Company, Richland, Washington.

HSRCM-1, Hanford Site Radiological Control Manual, latest revision, West inghouse Hanford Company, Richland, Washington.

WHC-SD-WM-OMM-024, Rev. 0, Surface Moisture Measurement System Operation and Maintenance Manua 7, Westinghouse Hanford Company, Richland, Washington.

WHC-SD-WM-WP-318, Rev. 0, Surface Moisture Measurement System Acceptance Testing Work Plan, Westinghouse Hanford Company, Richland, Washington.

WHC-SD-WM-DRD-002, Rev. 0, Design Requirements Document (DRD) for the Surface Moisture Measurement System, Westinghouse Hanford Company, Richland, Washington.

WHC, 1996a, Surface Moisture Monitoring System Installation Assembiy, drawing H-14-100458, Westinghouse Hanford Company, Richland, Washington.

WHC, 1996b, Surface Moisture Monitoring System Deployment Enclosure, drawing H-14-100459, Westinghouse Hanford Company, Richland, Washington.

WHC, 1996c, Surface Moisture Monitoring System Deployment Arm, drawing H-14-100460, Westinghouse Hanford Company, Richland, Washington.

WHC-CM-6-1, "Standard Engineering Practices".

H-14-100471, Driver Side Electronics Enclosure Surface Moisture Measurement System Wiring. 
WHC-SD-WM-ATP-182, REV. 0

H-14-100485, Surface Moisture Measurement System Deployment Enclosure Wiring. ANSI/IEEE Standard 829-1983, "IEEE Standard for Sof tware Test Documentation".

Ritter, G. A., 1995, Surface Moisture Measurement System Operation and

Maintenance Manual, WHC-SD-WM-OMM-024, Rev. 0, Westinghouse Hanford

Company, Richland, Washington. 
WHC-SD-WM-ATP-182, REV. 0

\section{ELECTRICAL AND MECHANICAL ACCEPTANCE TEST PROCEDURE \\ FOR ELECTROMAGNETIC INDUCTION \\ MOISTURE MEASUREMENT SYSTEM}

\section{$1-1.0$ INTRODUCTION}

\section{1-1.1 PURPOSE}

The purpose of this section is to verify that the mechanical and electrical features of the ElectroMagnetic Induction (EMI) probe are operating as designed, and that the unit is ready for field service.

\section{1-1.2 SCOPE}

This section addresses testing of the EMI probe hardware. Hardware testing will be performed at the $306 \mathrm{E}$ Facility in the 300 Area. The scope of tests to be performed at the facility is described in the following sections.

\section{1-1.2.1 Testing Objectives at the 306E Facility}

- Perform pre-operational check of the electrical system.

- Perform continuity tests of electrical wiring for the EMI system.

- Verify that the intrinsic safety barriers have been installed correctly.

- Verify the operation of the EMI probe and complete system.

- Collect typical data for a set of conductivities.

- Measure the weight of the EMI probe.

- Perform overall "loop check" on the system by measuring conductivity of conductivity standards to verify that the EMI probe and supporting electronics are functioning satisfactorily. 
WHC-SD-WM-ATP-182, REV. 0

\section{1-2.0 TEST CONTROLS}

\section{1-2.1 RESPONSIBILITIES ASSOCIATED WITH TESTING AT 306E}

1-2.1.1 306E Facility Management D. G. Panther, J. R. Thielges

- Provide space in the $306 \mathrm{E}$ high bay for performing testing.

1-2.1.2 WHC EMI/SMMS Project Engineer G. F. Vargo Jr.

- Identify and specify testing requirements for the EMI.

- Approve the ATP and Acceptance Test Report (ATR).

- Provide technical expertise during testing of the EMI.

- Approve acceptability of test activities and results.

1-2.1.3 Responsible Engineers

Facility Representative: D. B. Graves

Mechanical (ME): T. I. Stokes

Electrical (EE): S. D. Tomich and/or M. Gimera

NOTE: The responsible engineer may perform test performer activities.

- Act as the person in charge for test preparation and performance.

- Identify equipment and facilities for testing.

- Ensure informal testing and inspection is complete.

- Act as a liaison with the Quality Assurance Engineer (QE) and other participants for testing activities, as required.

- Ensure Hanford Job Hazards Analysis checklist is complete.

- Conduct pre-job briefing/readiness review prior to initiating test.

- Provide overall responsibility for maintaining and controlling testing to ensure compliance with the ATP.

- Approve field changes to the ATP.

- Take necessary action to resolve exceptions to the ATP.

- Approve acceptability of test activities and results.

1-2.1.4 Test Performer [as approved by the responsible engineer(s)]

- Perform testing in accordance with the ATP. 
WHC-SD-WM-ATP-182, REV. 0

- Record test data and observations as specified in the ATP.

- Record authorized field changes to the ATP.

- Record exceptions to the ATP on "Exceptions to EMI Acceptance Test" sheets (provided with the ATP).

- Prepare/issue the ATR.

1-2.1.5 Quality Assurance Engineer (QE) M. L. McElroy

- Review and approve the ATP and ATR.

- Ensure that quality requirements are defined and satisfied for the test.

- Witness conductance of acceptance testing as required. Testing may proceed per the ATP without a QE present.

1-2.1.6 Quality Control Inspectors (QC)

- Monitor test activities and provide signature verification, as required by the ATP. The $Q E$ or the responsible engineer may request QC witness of testing not specifically requested in the ATP.

The names of the test performers and responsible engineers for this ATP shall be documented in the ATR.

\section{1-2.2 TEST DATA}

- All test data, pertinent observations, and off-normal events shall be recorded in Section 1-5.0 (306E TEST PROCEDURE). If additional space is required, the data shall be recorded on an observation/results data sheet (provided in Appendix A) or equivalent.

- An ATR shall be prepared by EMI personnel to publish all data gathered during testing activities.

\section{1-2.3 TEST CONFIGURATION}

- The drawings and engineering documents that establish the equipment test configuration are listed in the REFERENCES.

- Additional documents required to perform, document, or validate a test (sketches, calibration sheets, etc.) will be referenced in or attached to the ATR. 
WHC-SD-WM-ATP-182, REV. 0

\section{1-2.4 PROCEDURE CONTROL}

A controlled test procedure package shall be used for testing and shall include as a minimum single copies of the following:

- This ATP.

- SMMS Operation and maintenance manual, WHC-SD-WM-OMM-024.

The package may also include other information that is directly applicable to testing.

Changes to the test procedure are permitted. Minor procedure changes such as editorial changes to a step, clarification of a step or steps, elimination or addition of a step, or limited sequential changes of steps, shall be noted in the procedure by redline entries and noted in the test procedure package giving the reason for the change. Redlined changes shall be documented in the ATR. The test performer shall make red-ink changes with the concurrence of the responsible engineer. Approvals will be documented by the responsible engineer's initials on the rediined item. Lack of immediate redline approval does not constitute a test hold. Continued test progress is at the discretion of the responsible engineer.

\section{1-2.5 RETEST PROCEDURE CONTROL}

- If a retest is required, then data sheets, new procedures, or additiona? copies of the applicable procedure sections of this ATP may be used.

- The addition of procedure sections to be used for retest shall be added to the test procedure package, concurred with by the WHC QE representative, and formally released in the ATR.

\section{1-2.6 EXCEPTIONS TO ACCEPTANCE TEST SECTION}

Exceptions to the test are dispositioned and agreed to by all witnesses. Actions taken regarding disposition are noted on the "Exceptions to EMI Acceptance Test" (Appendix B) sheet. Typical dispositions are:

- Test approved with exceptions (i.e., rerun of the acceptance test unnecessary).

- ATP step(s) affected to be repeated after the discrepancy has been corrected.

- Entire acceptance test to be repeated after the discrepancy has been corrected.

\section{1-3.0 TEST CONDITIONS AND EQUIPMENT REQUIRED}

\section{1-3.1 TEST FACILITY}

Acceptance testing of the EMI/SMMS will be conducted at the $306 \mathrm{Facility}$ 
WHC-SD-WM-ATP-182, REV. 0

in the 300 Area. The testing will be performed at the 306E Facility, in the building high bay or area adjacent to the facility.

\section{1-3.2 EQUIPMENT REQUIRED FOR TESTING AT $305 E$}

The following equipment will be required for testing at 306E. Readily available tools, such as standard wrenches and screwdrivers, are not included.

- EMI probe and instrument (Zetec MIZ-40A)

- EMI/SMMS deployment device

- Data acquisition van

- EMI/SMMS interconnecting cables

- Electrician's hand tools and multimeter for continuity testing and troubleshooting of electrical system

\section{1-3.3 FIELD TESTING OPTION}

Field testing is an optional method of executing this ATP. Since the entire SMMS system has undergone rigorous testing, the EMI ATP represents a function test of only those components added to the system. The EMI components and this ATP are relativeiy simple and easy to test. Therefore the EMI ATP can be accomplished in the field if necessary due to project demands in the event of a SMMS deployment. The same equipment is required as listed in Section 1-3.2.

\section{1-4.0 - SAFETY PRECAUTIONS AND CONTROLS}

Only the responsible engineers and/or their approved personnel shall operate the EMI during performance of this ATP. A Hanford Job Hazards Analysis Checklist will be completed under the guidance of a representative from Industrial Health and Safety. A pre-job meeting will be held prior to the test performance to brief test personnel on the hazards unique to the EMI/SMMS equipment and to review all procedures, drawings, and other engineering documents required to complete the test. Safety precautions for operation of the EMI/SMMS are identified in WHC-SD-WM-OMM-024. Safety precautions applicable to this ATP have been repeated here and are listed in the sections below. THESE PRECAUTIONS SHALL BE FOLLOWED FOR THE PERFORMANCE OF THIS ATP.

\section{1-4.1 PERSONNEL PRECAUTIONS}

1-4.1.1 In case of fire or other emergency in the van, all power shall be secured by moving circuit breaker CB-l to the OFF position (the main circuit breaker located on the power distribution panel).

1-4.1.2 A carbon monoxide (CO) monitor is located in the DAV. If the Co monitor warning signal occurs, turn off the van engine, and exit the van leaving the doors open. Wait for a minimum of 5 minutes for the CO to dissipate. The co monitor warning signal will automatically 
WHC-SD-WM-ATP-182, REV. 0

stop and reset when the unsafe $C O$ level no longer exists.

1-4.1.3 Exhaust piping becomes hot during operation and remains hot for a while after stopping an engine (e.g., van, generator, decon pumps). Be careful not to touch a muffler while it is hot.

1-4.1.4 The cables routed from the van to the EMI/SMMS deployment device equipment present a personnel trip/fall hazard. The cables shall be isolated by barricades to the extent possible to alleviate the trip hazards.

1-4.1.5 Electrical test equipment shall only be used by qualified personnel who are trained on the operation and limitation of the equipment.

1-4.2 EQUIPMENT PRECAUTIONS

1-4.2.1 Supply power to a subsystem must be OFF when connecting or disconnecting any electrical equipment or cables to that subsystem.

1-4.2.2 Failure to hook up or remove the power and interconnecting cables in the sequence prescribed in this manual could result in generation of unacceptable equipment voltages and in electrical arcing or sparking.

1-4.2.3 The EMI/SMMS deployment device could be bent if not supported or lifted correctly when in the horizontal position.

\section{1-5.0 306E TEST PROCEDURE}

\section{1-5.1 PREREQUISITES}

\section{1-5.1.1 Pre-job Meeting}

Conduct a "pre-job meeting" of operations including a review of all procedures, drawings, safety hazards, and other engineering documents required to complete the test. Personnel who have attended the pre-job meeting shall sign the attendance form given in Appendix $C$.

\section{1-5.1.2 Stage Equipment}

Verify that the equipment 1isted in Section 1-3.2 is staged in the test area. Verify that no interconnections have been made.

Test Engineer's signature Date

\section{1-5.2 ELECTRICAL CONTINUITY CHECKS}

Electrical continuity measurements of all EMI wiring shall be performed in this section. The following wiring diagrams shall be used to check electrical continuity.

- H-14-100471, Driver Side Electronics Enclosure Surface Moisture Measurement System Wiring. 
- H-14-100485, Surface Moisture Measurement System Deployment Enclosure Wiring.

For each drawing listed above, a test control copy shall be identified by clearly marking in red ink "TEST CONTROL COPY" above the title block on the drawing. Using a multimeter set up to measure ohms, the responsible EE and an independent electrical reviewer will verify continuity (maximum $1 \mathrm{lohm}$ resistance) of each conductor on each drawing. The responsible EE or independent electrical reviewer will initial and date next to each termination point verified on the test control copy of the drawing. The test control copies of the drawings shall be saved in project files.

\section{WARNING}

Verify that circuits are de-energized before performing continuity checks.

Electrical continuity checks on the drawings listed above have been completed. Discrepancies, if any, have been listed on exceptions sheets (Appendix B).

Accept/Reject (circle one)

Test Instrument Used Calibration Date

Test Engineers signature Date

$Q A / Q C$ signature Date

\section{1-5.3 ELECTRICAL SYSTEMS OPERATIONAL CHECKOUT}

The EMI/SMMS is a stand-alone system with no connections to existing tank farm utilities required. Power for the system operation is supplied as part of the data acquisition van, but can also be supplied by a site service receptacle. All other power alternatives have been tested with the SMMS ATP.

\section{1-5.3.1 EMI Electrical Cable Connections}

Verify that the following circuit breakers and disconnect switches are in the OFF position:

- Van power distribution panel: al1 circuit breakers, CB-1 through CB-15 -OFF.

- Van generator: AC circuit breaker -OFF. 
WHC-SD-WM-ATP-182, REV. 0

Connect the electrical cables to the equipment as follows.

- W1 to DAV J1 and to EMI/SMMS electrical junction box J11 (probe signals).

- W7 to DAV J7 and to EMI/SMMS electrical junction box $J 17$ (auxiliary instrument signals).

- W8 to DAV 38 and to EMI/SMMS electrical junction box J18 (auxiliary instrument signals).

- W9 to DAV $J 9$ and to EMI/SMMS electrical junction box J19 (probe signals).

Connect EMI system using EMI/SMMS Conversion Procedure (Appendix D)

Test Engineer's signature

Date

$Q A / Q C$ signature

Date

\section{1-5.3.2 Intrinsic Safety Barrier}

1-5.3.2.1 Measure the resistance between the intrinsic safety barriers mounting bus bar and the EMI/SMMS mast. Record equipment calibration information. QC verify resistance reading equal to infinity.

Instrument \#:

Reading

1-5.3.2.2 Visually inspect the intrinsic barriers and verify that they are adequately installed and ready for field service.

Test Engineer's signature

Date

$Q A / Q C$ signature

Date

\section{1-5.3.3 Grounded and Bonded Equipment}

All in-tank hardware (deployment device and EMI probe) must be grounded, or bonded to a grounded piece when the equipment is installed in a waste tank. Grounding is the assurance that a given component has very little to no potential voltage difference with respect to earth ground. Bonding is the assurance that individual components have little to no potential with respect to each other. 
WHC-SD-WM-ATP-182, REV. 0

1-5.3.3.1 For the deployment device (H-14-100458), verify that the resistance between any two components in contact is less than 25 ohms. Record equipment calibration information. QC verify readings.

Instrument \#:

Maximum Reading

1-5.3.3.2 Verify that the resistance between the EMI probe housing (stainless steel) and ground is less than 25 ohms. QC verify readings.

Reading

Accept/Reject (circle one)

Test Engineers signature

Date

QA/QC signature

Date

1-5.4 DEPLOYMENT DEVICE PREOPERATIONAL TEST

1-5.4.1 Weight Measurements

Weigh the EMI probe with cable head attached.

Reading Instrument \# Calibration Date

Accept/Reject (circle one) (251bs or greater - accept)

Test Engineers signature

Date

QA/QC signature

Date

\section{1-5.5 TEST POWER SUPPLY FOR EMI}

Connect external AC van power, turn on appropriate circuit breakers for EMI power. Apply power to the Zetec MIZ-40A and deployment enclosure. 
1-5.5.1 Verify that power (120 VAC $\pm 10 \mathrm{VAC})$ is available for the following components:

- computer and flat panel computer display

- deployment device instrumentation (compass, encoders)

- van service receptacle

- Zetec MIZ-40A and probe

Accept/Reject (circle one)

Test Engineers signature Date

$Q A / Q C$ signature Date

\section{1-5.6 FUNCTIONAL TEST}

This section is intended to perform an initial checkout of the operability of the deployment device with the EMI probe.

1-5.6.1 Place a $0 \mathrm{~ms} / \mathrm{cm}$ conductivity standard on the floor below the suspended EMI probe.

1-5.6.2 Lower the probe to approximately 5 inches above the liquid surface.

1-5.6.3 Activate the data acquisition computer and manually lower the probe until it touches the liquid surface.

1-5.6.4 Raise the probe to 5 inches above the liquid and halt data acquisition.

1-5.6.5 Wipe the probe face clean with a dry towel.

1-5.6.6 Deactivate the data acquisition computer and store the file on disk.

1-5.6.7 Repeat 1-5.6.1 through $1-5.6 .6$ for $5 \mathrm{~ms} / \mathrm{cm}, 10 \mathrm{~ms} / \mathrm{cm}$, and $40 \mathrm{~ms} / \mathrm{cm}$ conductivity liquids.

1-5.6.8 Review the data per the software section 2 .

Test Engineer's signature

Date

QA/QC signature

Date 


\section{WHC-SD-WM-ATP-182, REV. 0 \\ SOFTWARE ACCEPTANCE TEST PROCEDURE \\ FOR ELECTROMAGNETIC INDUCTION \\ MOISTURE MEASUREMENT SYSTEM}

\section{2-1.0 INTRODUCTION}

\section{2-1.1 PURPOSE}

This section presents both a test plan and acceptance test procedures for testing the software that was developed to operate the ElectroMagnetic Induction (EMI) moisture measurement system. The selected method of design verification is qualification testing.

\section{2-1.2 SCOPE}

The testing described in this section covers the software that acquires data for the EMI system. In addition to the software, this testing will verify and validate the data acquisition and control hardware for the EMI system.

\section{2-2.0. SOFTWARE TEST PLAN}

The software acceptance test that is the subject of this section will test the features of the EMI software described herein.

\section{2-2.1 PERSONNEL REQUIREMENTS}

Each organization participating in the conduct of this test will designate personnel to assume the responsibilities and duties as defined herein for their respective roles. The names and signatures of these people shall be provided to the Test Engineer for listing on the Test Engineer's copy of the Test Data Sheet prior to the performance of any part of this test.

\section{2-2.1.1 Test Engineer}

The Test Engineer's responsibilities are as follows:

- Notify all interested parties when a change is made in the testing schedule.

Record exceptions and test steps which are not performed.

- Notify the Test Performer of exceptions when an exception is made.

\section{2-2.1.2 Test Performer}

The Test Performer's responsibilities are as follows:

- Verify instruments are in current calibration.

- Perform the test as described in this section. 
- Stop any test which, in the judgment of the Test Performer, may cause damage to the system or present a unsafe condition.

- Coordinate efforts with all other assigned test performance party members.

- Observe tests and record test data (if any).

\section{2-2.1.3 QA Witness}

The QA Witness shall observe the testing and provide a signature that the test procedures were followed and results accurately recorded on the data sheets.

\section{2-2.1.4 Other Witnesses}

No further witnesses are required during testing but interested observers will be allowed.

\section{2-2.2 FEATURES TO BE TESTED}

This section lists each of the software features that will be tested. Inherent in testing the software is some hardware testing. The extent to which the hardware will be tested is explained in each subsection. Figure 2-1 shows the operator interface screen that will be helpful in understanding the descriptions and procedures that follow.

The purpose of the EMI system software is to obtain data from which moisture may be determined by post processing.

\section{2-2.2.1 Operator Interface Controls}

The EMI instrumentation is controlled by an operator. The front panel uses only one control, the "Take Measurement" button (changes to "Stop Measurement" when pressed). The control is accessed by using the computer's mouse to select the button's icon.

When the "Take Measurement" button is "pressed" the computer will acquire data from the Zetec MIZ-4OA and the signal conditioners. Data acquisition will begin and continue until the button is pressed again. During data acquisition, text on the button will change from "Take Measurement" to "Stop Measurement." When the test is stopped, by pressing the "Stop Measurement" button icon, the acquired data will be written to a disk file.

This window allows the operator to do any of the following:

- Start the EMI data acquisition.

- Stop the data acquisition and save the file. 


\section{2-2.2.2 Operator Interface Indicators}

The operator interface indicators consist of a numerical display of the probe position, a graphical display of probe position and a graph with two sets of data piotted per channel for three channels.

When each conductivity is tested, the hardware associated with acquiring the data for each readout will also be tested. When comparing the information displayed and recorded to file with the reading from prior calibrations, these tests will provide an overall assessment of system accuracy.

\section{2-2.2.2.1 Probe Position}

The probe position is displayed graphically. The display shows both the compass heading and the distance from the riser centeriine on a polar plot.

The only test to be performed will verify the probe height. This test must be performed with the deployment system suspended horizontally and the probe vertically.

\section{2-2.2.2.2 Digital Displays}

The probe position will also be displayed on digital meters located at the deployment device. These digital displays are controlled by the computer and include compass position in degrees, radial distance in feet, and depth in inches.

Operation of the digital displays were verified during the SMMS ATP.

\section{2-2.2.2.3 EMI Graph}

The EMI graphs each raw data signal for the three channels from the probe. The operation of the probe graphs can verify operation of the probe.

\section{2-2.2.3 Data Recording}

While it is important to obtain accurate data, it is also necessary to save that data in a form that can be analyzed later. The data will be stored to a computer disk file in a text format. Both the ability to record and the information recorded must be tested. The file created by asserting the "Take Measurement" icon may be viewed with a text editor.

\section{2-3.0 ACCEPTANCE TEST PROCEDURE}

This section provides the instructions to perform acceptance testing on the EMI software. Although these procedures usually provide step-by-step instructions, this section on occasion makes reference to the Operator's Manual and the Installation Instructions. 
WHC-SD-WM-ATP-182, REV. 0

\section{2-3.1 INSTRUCTION SECTION}

\section{2-3.1.1 System Setup}

Testing will be conducted in the 306E Lab. The hardware should be setup in accordance with the instructions in Section 5.1, "DAV Startup Sequence" of the OM\&M. A $120 \mathrm{VAC} \pm 10 \mathrm{VAC}$ power source (15 Amp) will be connected to the data acquisition van. Software start-up is also covered in the OM\&M.

2-3.1.2 Take Measurement Button and Graph Display

Test successful initialization.

2-3.1.2.1 Turn on power to instrumentation per Section 5.1 of the OM\&M. Computer screen should show Windows_ interface.

2-3.1.2.2 Start the EMI program by double clicking on EMI.vi icon.

2-3.1.2.3 The EMI front panel should now be displayed on the computer screen (see Figure 2-1). Note the result on the test data sheet.

2-3.1.2.4 Click on the LabVIEW_ "run" icon.

2-3.1.2.5 Position the probe above the calibration standard. The calibration standard is a container which holds a conductivity solution.

2-3.1.2.6 Place the probe 5 inches above the liquid surface.

2-3.1.2.7 Press the "Take Measurement" control on the front panel (Figure 2-1).

2-3.1.2.8 Lower the probe to the liquid surface and back to 5 inches above.

2-3.1.2.9 Press the "Stop Measurement" control on the front panel (Figure 2-1).

2-3.1.2.10 Note whether the graph display updated. Record this result to the data sheet.

2-3.1.3 Data File Content

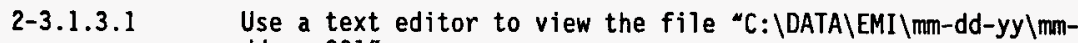
dd-yy.001".

${ }^{1}$ is a registered trademark of MicroSoft Corp. of Redmond, Washington. 
2-3.1.3.2 Verify the header information in the file matches the following:

File: mm-dd-yy.001

[Date and time stamp]

Program: EMI.vi v1.0

Probe Position: Compass heading $X X X{ }^{\circ}$ Radial Distance: $X X f t$. Depth: $X X X$ in. Depth Ch_3_Vert Ch_3_Horz Ch_2_Vert Ch_2_Horz Ch_1_Vert Ch_1_Horz

2-3.1.3.3 Record the results from Step 2-3.1.3.2 to the test data sheet.

2-3.1.3.4 Using the text editor, verify that data exists for each heading. Data should consist of seven columns of data. The number of rows of data depends on the recording duration ( $t$ ime between "Take Measurement" and "Stop Measurement").

2-3.1.3.5 Record the results from Step 2-3.1.3.4 to the test data sheet.

\section{2-3.2 TEST EXECUTION SECTION}

\section{2-3.2.1 TEST DATA SHEETS}

The test data sheets are shown on the following pages.

Please print name of test personnel below:

Test Engineer:

Test Performer:

QA/QC Rep:

Test 2-3.2.2 Take Measurement Button and Detector Graphs

Step 2-3.2.2.1

Is EMI front panel displayed on the screen?

Test Engineer:

Date

QA/QC Rep:

Date 
WHC-SD-WM-ATP-182, REV. 0

Step 2-3.2.2.2

Do probe graphs update on the screen?

$$
\text { Y }
$$

N

Test Engineer:

Date

QA/QC Rep:

Date

\section{Test 2-3.2.3 Data File Content}

Step 2-3.2.3.1

Does data file contain the header information expected in Step 23.1.3.2.

Test Engineer:

Date

QA/QC Rep: Date

\section{Step 2-3.2.3.2}

Does the data file indicate probe channel 1 and conductivity 1 ?

Does the data file indicate probe channel 2 and conductivity 2 ?

Does the data file indicate probe channel 3 and conductivity 3 ?

\section{Y}

Test Engineer:

Date

QA/QC Rep:

Date 
WHC-SD-WM-ATP-182. REY. 0

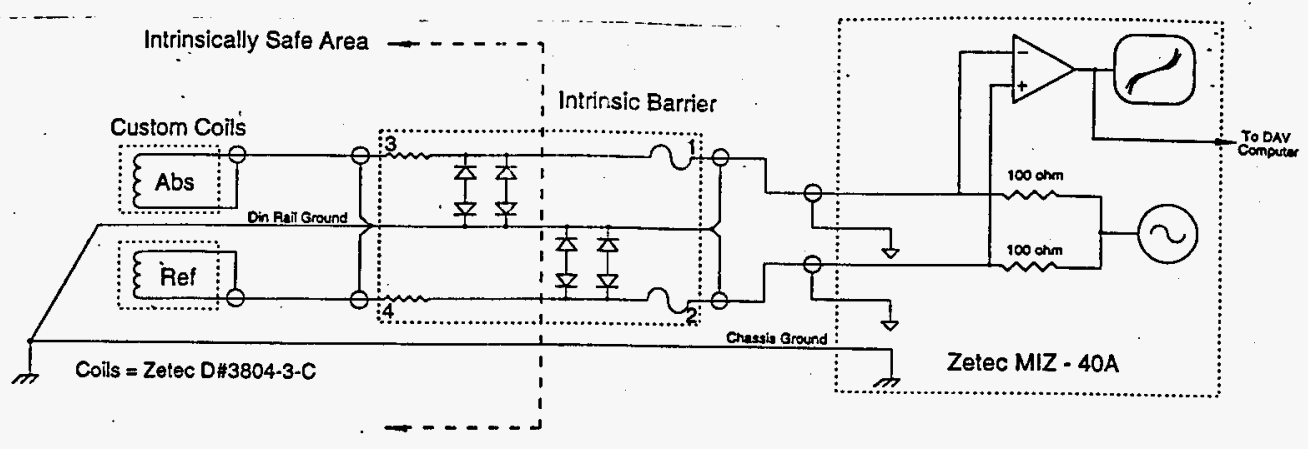

EMI System Schematic

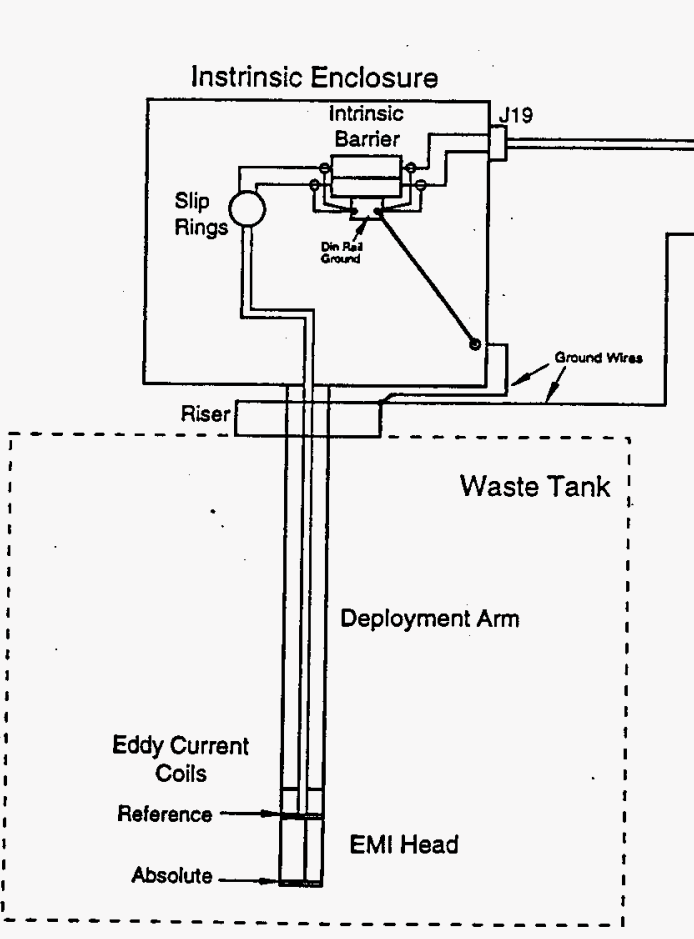

Figure 1-1 
WHC-SD-WM-ATP-182, REV. 0

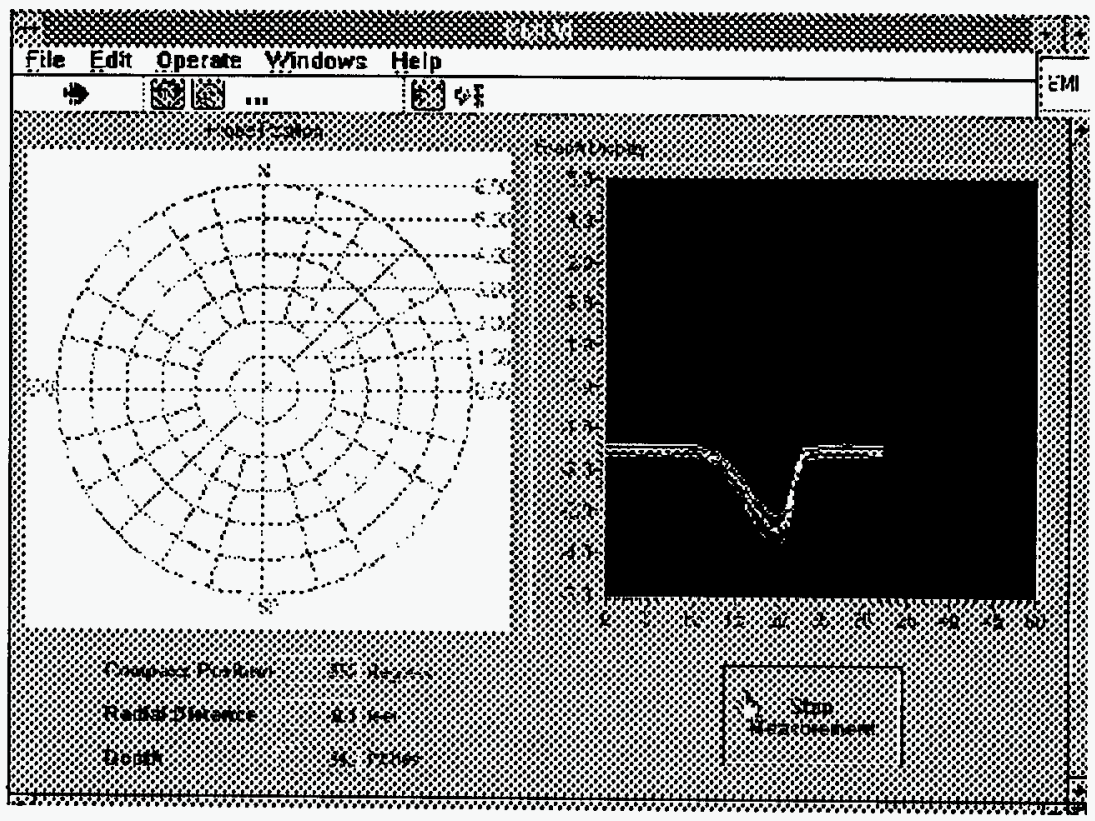

FIGURE 2-1 OPERATOR INTERFACE SCREEN 
WHC-SD-WM-ATP-182, REV. 0

\section{APPENDIX A}

EMI MOISTURE MEASUREMENT SYSTEM

FUNCTIONAL TESTING

OBSERVATION/RESULTS SHEET

Page A-1 
WHC-SD-WM-ATP-182, REV. 0

EMI MOISTURE MEASUREMENT SYSTEM

FUNCTIONAL TESTING

OBSERVATION/RESULTS SHEET

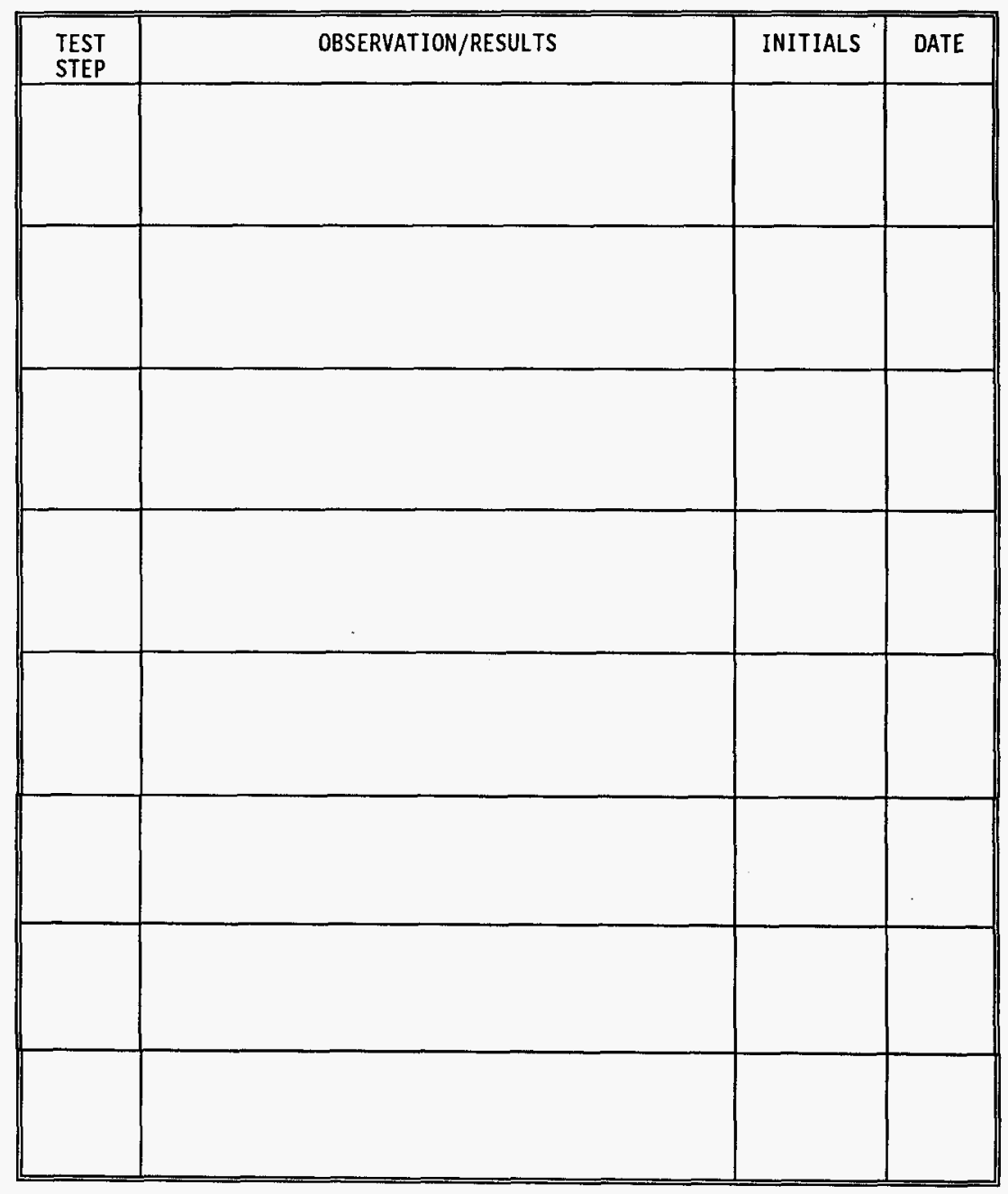

Page A-2 
WHC-SD-WM-ATP-182 Rev. 0

APPENDIX B

EXCEPTIONS TO EMI ACCEPTANCE TEST 
EXCEPTIONS TO EMI ACCEPTANCE TEST

Titie of Test: EMI Moisture Measurement System Test

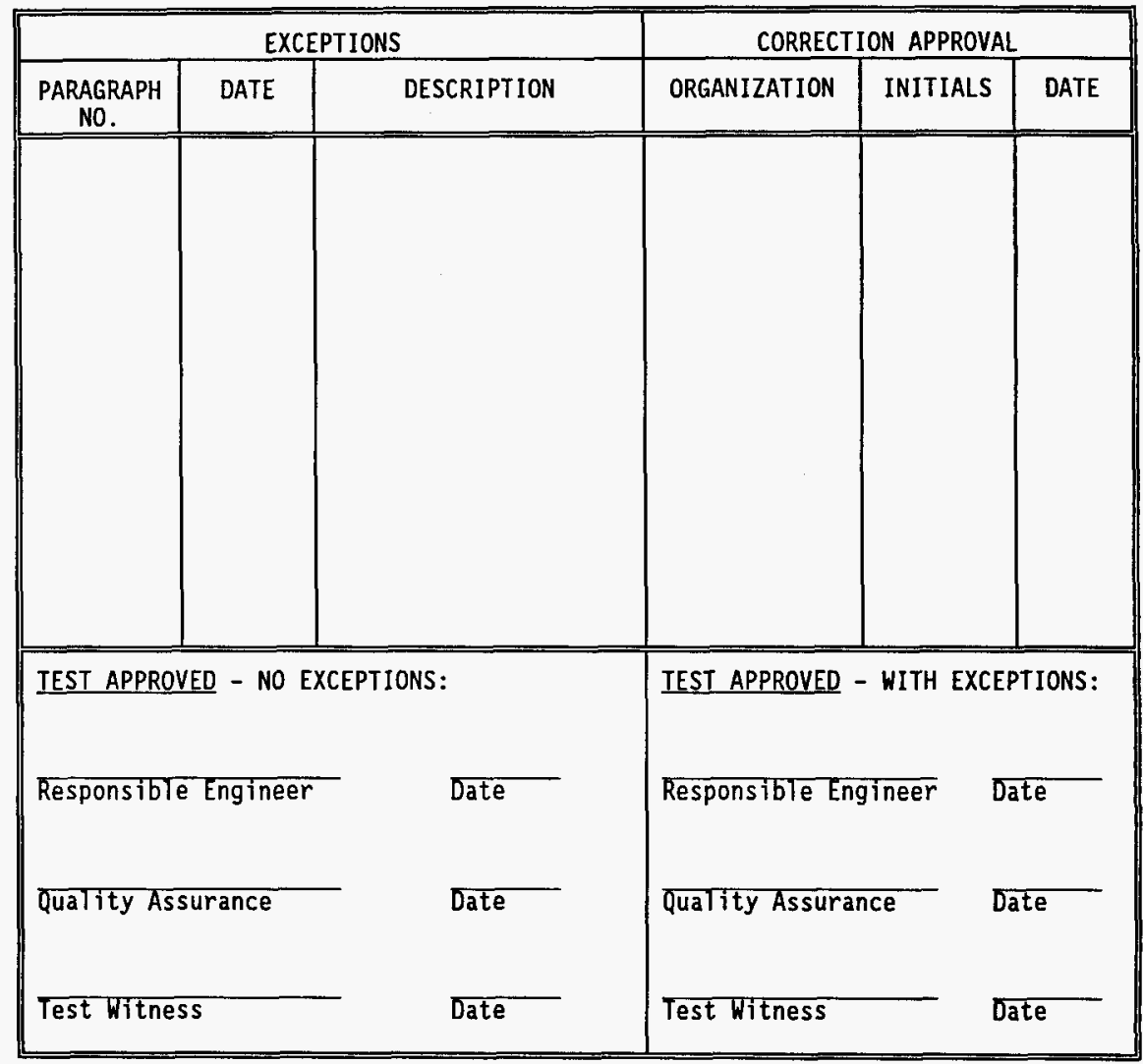


WHC-SD-WM-ATP-182 Rev. 0

\section{APPENDIX C}

PRE-JOB SAFETY MEETING FORM

AND ATTENDANCE ROSTER

Page C-1 
PRE-JOB SAFETY MEETING FORM

AND ATTENDANCE ROSTER

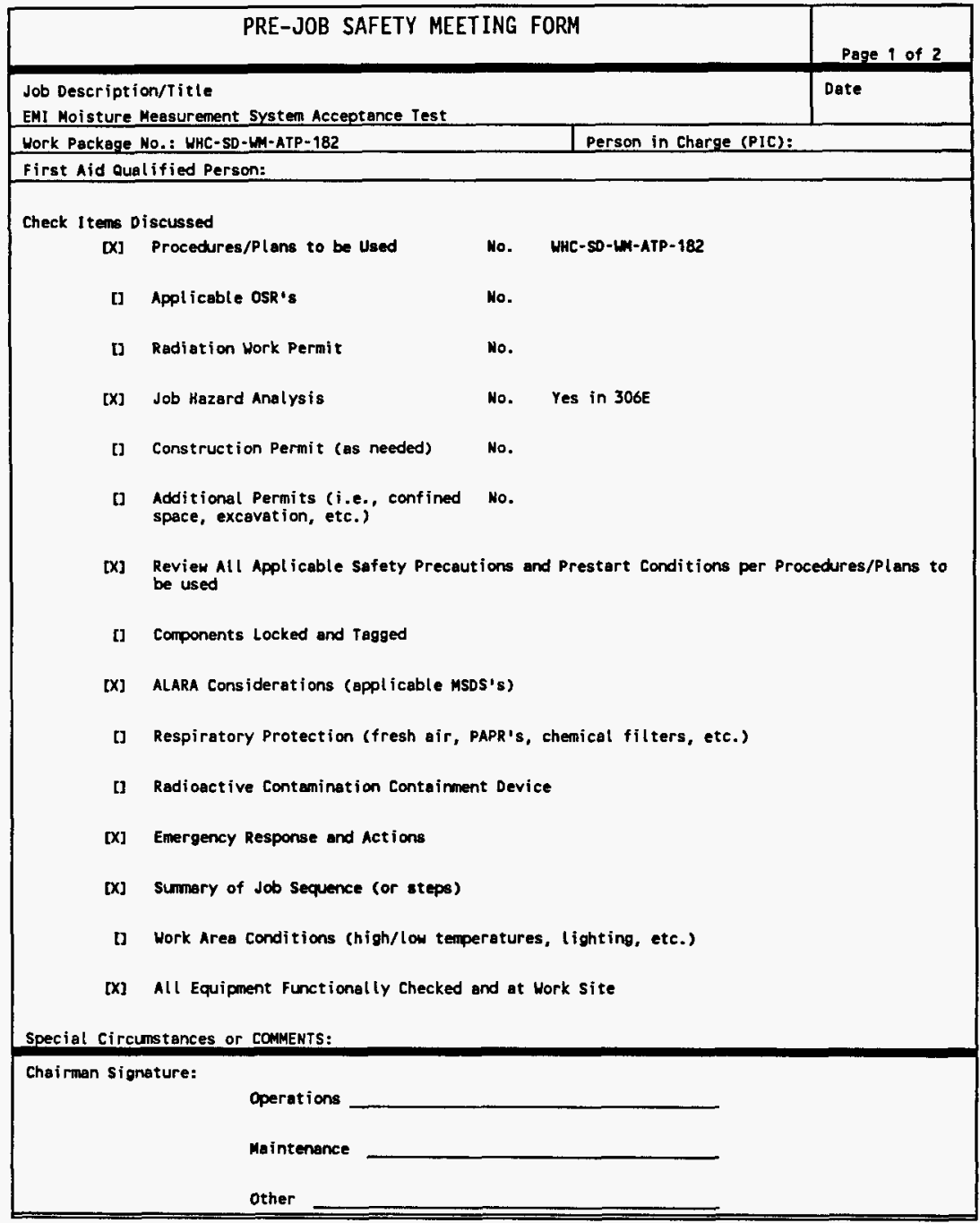

Page $\mathrm{C}-2$ 


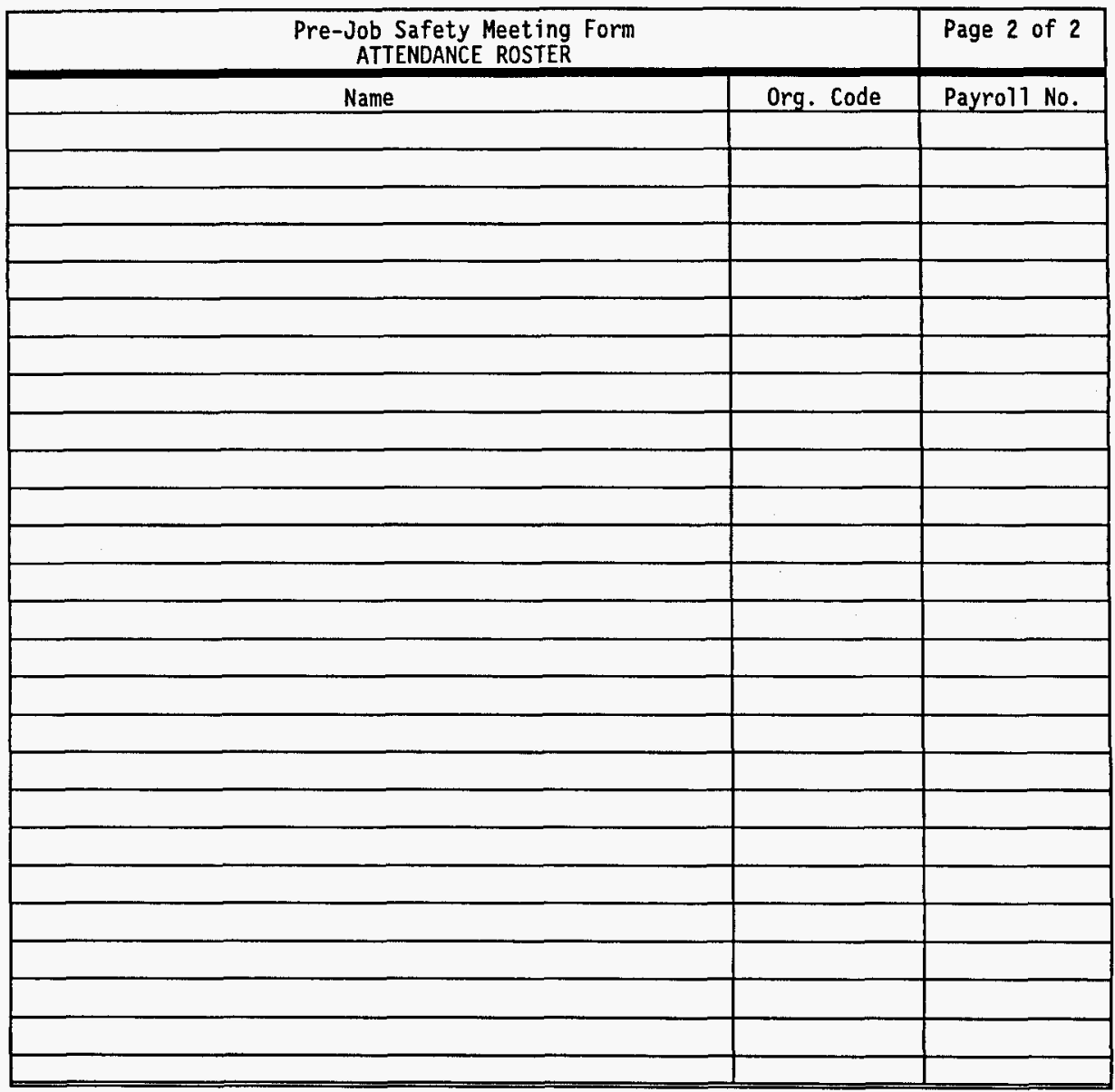


WHC-SD-WM-ATP-182 Rev. 0

APPENDIX D

EMI/SMMS Conversion Procedure

Page 0-1 


\section{EMI/SNMS Conversion Procedure}

\section{EMI/SMMS Enclosure}

- Open the enclosure and locate the 2 RG-174U coax cables in the raceway above MPI (moisture probe interface board) in the mast head enclosure. These cables are labeled IB06-1 (red banded) and IBO6-2 (yellow banded).

- Disconnect J19B-MP1 J6 from the MP1 circuit board and connect it to IB06-1 (red). Disconnect J19D-MP1 J7 from the MP1 circuit board and connect it to IBO6-2 (yellow).

- On the slip ring assembly SLC-01 remove SLC-01-J1-IB01 from SLC-01 J1 and remove SLC-01-J2-IB02 from SLC-01 J2.

- Connect IB06 3 (red) from the EMI Only barrier to SLC-01 J1 and connect IBO6 4 (yellow) from the EMI Only barrier to SLC-01 J2.

- Secure any disconnected wires with wire ties.

- This completes the enclosure modifications to use the EMI probe with the SMMS deployment device.

\section{$\underline{\text { Van }}$}

- Insure that all of the SMMS cables are connected from the deployment enclosure to the van.

- Install the Zetec MIZ-40A into the passenger side Cabinet B on the EMI shelf. During this installation connect the 25 pin $D$ connector from the shelf signal conditioning to the MIZ-40A analog outputs. Al so connect the RGI74-U coax adapter to probe inputs, coils A\&B. Both switches (NRM/DP-) on the rear of the MIZ-40A should be in the NRM position. Connect the $A C$ power cord and plug the $A C$ bus strip into the front outlet of the UPS near the floor.

- On the front of the drivers side cabinet $\mathrm{H}-14-100470-020$ at the SMMS CPU shelf, move the RG174-U coax at the right side from SMMS Red to EMI Red. Move the SMMS Blue to the EMI Blue.

- Disconnect the SMMS parallel port cable on the CPU and connect the EMI data cable to the parallel port.

- The van is now ready to operate the EMI probe and acquire data. 